\title{
A novel anti-melanoma SRC-family kinase inhibitor
}

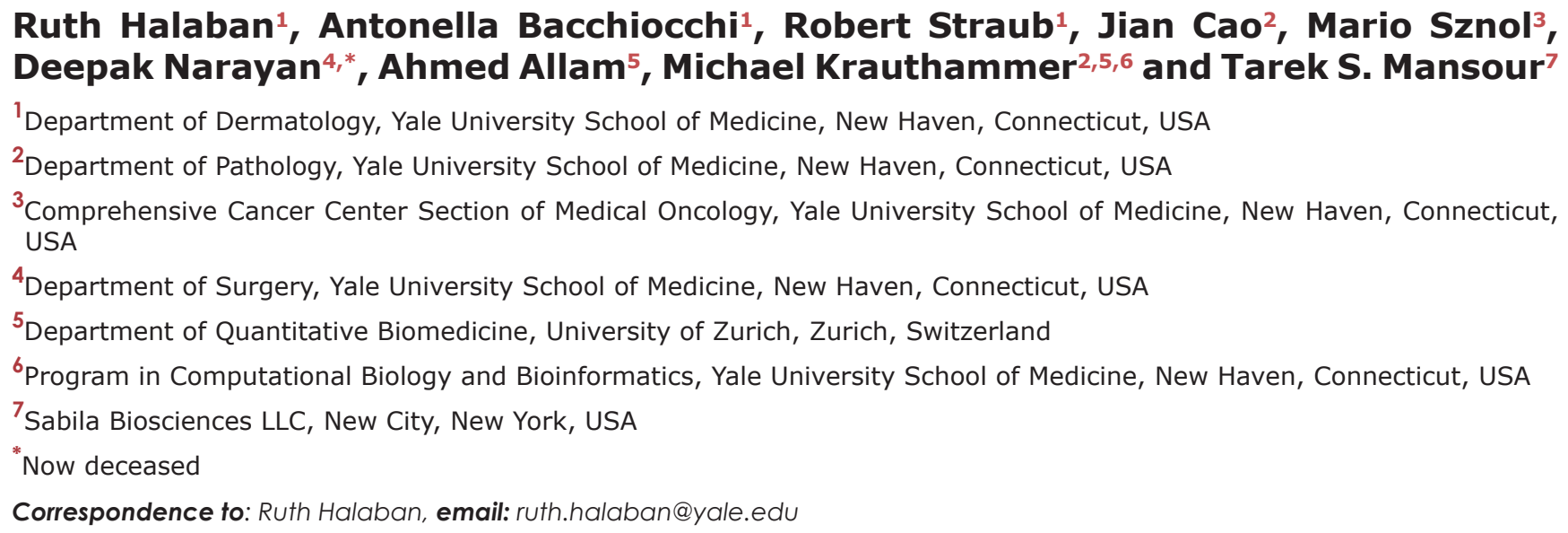
Keywords: melanoma; SRC-family kinase inhibitors; MAPK; MITF Received: December 26, $2018 \quad$ Accepted: March 04, $2019 \quad$ Published: March 19, 2019 Copyright: Halaban et al. This is an open-access article distributed under the terms of the Creative Commons Attribution License 3.0 (CC BY 3.0), which permits unrestricted use, distribution, and reproduction in any medium, provided the original author and source are credited.

\section{ABSTRACT}

The major drawback of melanoma therapy with BRAF and MAPK inhibitors is the innate and acquired drug resistance. We therefore explored alternative targets and developed a new compound, SAB298, that is a SRC-family kinase (SFK) inhibitor. The drug is cytotoxic to patient-derived melanoma cells regardless of oncogene expression and inhibits tumor growth in vivo. As expected, it inhibited SRC and PI3K activity, and had the additional property of ERBB2 inhibition, that lead to inactivation of the two ERK phosphatases PP2A and SHP2. In 57\% of the melanoma cell lines tested, the consequent increase in ERK activity lead to proteolytic degradation of its substrate, the lineage specific transcription factor MITF, likely contributing to growth arrest. Treatment with a combination of SAB298 and AZD6244 (selumetinib), induced a synergistic growth inhibition, suggesting that the new compound could be used in the clinic as a substitute for, or in combination with MAPK inhibitors.

\section{INTRODUCTION}

Current standard therapies for melanoma include treatments with checkpoint blockades or with vemurafenib and dabrafenib, small molecule inhibitors for BRAF and MEK. The combination therapy diminishes the activity of $\mathrm{BRAF}^{\mathrm{V} 600 \mathrm{E} / \mathrm{K}}$ present in $40-50 \%$ of melanomas $[1,2]$ and inhibits the mitogen-activated protein kinase (MAPK) pathway. However, there is an urgent need to identify new molecular pathways for targeting melanomas because of inherent or rapid emergence of resistance to MAPK inhibition [3-5]. In addition, melanomas that do not carry the BRAF oncogenes cannot be subjected to this type of therapy and are limited to treatments with immune checkpoint inhibitors, such as nivolumab, or combination of nivolumab with ipilimumab, approved by the FDA in 2016.
We sought to expand therapeutic possibilities using medicinal chemistry optimization strategies which led to the discovery of SAB298, a new kinase inhibitor that targets mostly members of the SRC-family kinase (SFK). SAB298 is an efficient inhibitor of a range of patient-derived melanoma cell lines, displaying a unique mechanism of action compared to other known SRC kinase inhibitors.

\section{RESULTS}

SAB298 is the most cytotoxic SFK inhibitor to melanoma cells

SAB298 is a synthetic small molecule that has emerged from a rational design strategy for receptor and 
non-receptor tyrosine kinases' inhibitor. It contains the pyrazolo[3,4- $d]$ pyrimidine core structure, has the $(3 S$, $4 S$ ) absolute configuration at the two stereogenic centers and features a substituted 1,2 dithiolane moiety that is unprecedented in kinase inhibitors (Figure 1).

We first tested the impact of SAB298 on NCI-60 human tumor cell lines that included eight melanomas (performed by the NCI Development Therapeutics Program). The results showed suppression of melanoma cell proliferation $\left(\mathrm{IC}_{50}\right.$ of $21-550 \mathrm{nM}$ ), with the $B R A F^{V 600 E}$ mutant melanoma cell line UCLA-SO-M14 (M14) being most sensitive (Supplementary Table 1). We therefore went on to screen the drug effect on a cohort of 30 patientderived short-term cultures of melanoma cell lines carrying $B R A F^{V 600 E / K}, N R A S^{Q 61 K / L / R}, N F 1^{\text {null }}, R A C 1^{P 129 S}, R A F 1$ or $B R A F$ fusion proteins, as well as other mutations identified by exome-capture sequencing (Table 1 and Supplementary Table 2). Overall, the drug was particularly cytotoxic to cell lines that did not carry oncogenic mutations in $B R A F$ or $N R A S$ (double-WT), displaying a range of $\mathrm{IC}_{50}$ between 81-717 nM (Median $=257 \mathrm{nM})$. Melanomas with $B R A F^{V 600 E / K}$ sub-grouped into lines that were sensitive $\left(\mathrm{IC}_{50}\right.$ 55-282, Median $=141 \mathrm{nM})$ or resistant $\left(\mathrm{IC}_{50} 500-2,477 \mathrm{nM}\right.$, Median $=697 \mathrm{nM}$ ), while the $N R A S^{Q 61 K / L / R}$ mutants required relatively high concentrations of SAB298 to induce growth arrest $\left(\mathrm{IC}_{50} 371-3,080 \mathrm{nM}\right.$, Median $\left.=752 \mathrm{nM}\right)$ (Figure 2A, $2 \mathrm{~B}$ and $2 \mathrm{C}$, summarized in $2 \mathrm{D}-2 \mathrm{~F}$ ). Interestingly, normal human melanocytes grouped with the resistant subtype $\left(\mathrm{IC}_{50}\right.$ $968 \mathrm{nM}$, Figure 2A, orange). The cytotoxicity of SAB298 was well demonstrated by the high values of AUC (Area Under the Curve) below the zero line for double wild-type melanoma cell lines (Figure 2F). Three-way Kruskal-Wallis analysis of the dot-plot display (Figure 2D) showed that the difference in the levels of response to SAB298 between the double-WT and NRAS-mutant melanoma cells were statistically significant, $p$-value $=0.002985$.

SAB298 $(0.5 \mu \mathrm{M}$ and $1 \mu \mathrm{M})$ induced apoptosis as measured by annexin staining and caspase activity (Supplementary Figure 1A-1C).
Comparing the potency of SAB298 to clinicallyrelevant SFK-inhibitors showed that dasatinib, bosutinib, saracatinib, SU6656 and imatinib (the latter targeting ABL, KIT and PDGFR), had very little or no inhibitory effect $\left(\mathrm{IC}_{50} \sim 10,000 \mathrm{nM}\right.$, Supplementary Figure 2A). On the other hand, UM-164, a modified dasatinib that binds to the inactive conformation of SRC kinase Asp-PheGly motif (DFG-out) and inhibits also p38 kinase [6], was effective independent of oncogenic mutations $\left(\mathrm{IC}_{50}\right.$ 50-3,000 nM) (Supplementary Figure 2B-2E). However, compared to SAB298, UM-164 was less effective inhibitor for $\sim 50 \%$ of the melanoma cell lines as indicated by the $\mathrm{IC}_{50}$ plots (Figure $2 \mathrm{G}$ ), and less cytotoxic, as shown by the low levels of AUC1 scores (Figure 2H, compare empty to solid dots, and supplementary Figure 2E). We also confirmed the anti-melanoma activity of SAB298 in vivo. Daily administration $(20 \mathrm{mg} / \mathrm{kg})$, significantly suppressed the growth of established YUSIK melanoma tumors, compared to placebo control $(p=0.0006)$ (Figure 2I).

SAB298 suppressed cell proliferation as effectively as the ERK and MEK inhibitors (SCH772984 and AZD6244, respectively), which displayed wide range of activity when tested on our cohort of melanoma cells $\left(\mathrm{IC}_{50}\right.$ 12->10,000 nM) [7]. In addition, SAB298 had synergistic inhibitory effect when combined with the MEK inhibitor AZD6244. The combination treatment dropped the $\mathrm{IC}_{50}$ values to $<10 \mathrm{nM}, 127 \mathrm{nM}$ and $43 \mathrm{nM}$ in the BRAF ${ }^{\mathrm{V} 600 \mathrm{E}}$ mutants YUSIK, 501 mel cells and the HRAS ${ }^{\mathrm{Q} 1 \mathrm{~K}}$ mutant YUROB cells, respectively (Figure 3). The combination treatment had statistically strong synergism assuming mutually exclusive and nonexclusive mode of action of AZD6244 and SAB298 across all three cell lines. The Combination Index (CI) values were between 0.1 and 0.3 based on the median-effect equation derived from the mass-action law principle $[8,9]$ to quantify synergism (see Supplementary Methods for details).

Altogether, the results show that SAB298 is an effective inhibitor of melanoma cell proliferation and can be used for targeted therapy in melanoma.

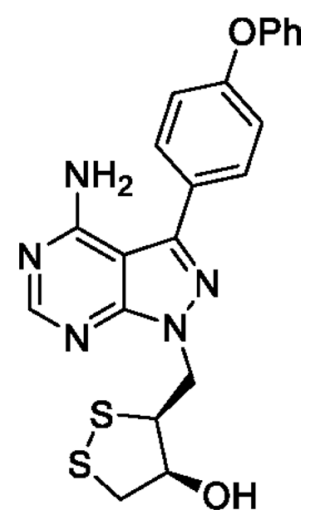

Figure 1: Structure of SAB298. The compound contains the pyrazolo[3,4- $d]$ pyrimidine core structure, has the $(3 S, 4 S)$ absolute configuration at the two stereogenic centers and features a substituted 1,2 dithiolane moiety that is unprecedented amongst kinase inhibitors. Its chemical name is $(3 S, 4 S)$-3-((4-amino-3-(4-phenoxyphenyl)-1H-pyrazolo[3,4-d]pyrimidin-1-yl)methyl)-1,2-dithiolan-4-ol. 
Table 1: Melanoma cell lines

\begin{tabular}{lc}
\hline Melanoma type & Number of specimens \\
\hline Sun-exposed & 17 \\
Acral & 5 \\
Ocular & 2 \\
Mucosal & 1 \\
Unknown & 5 \\
Total & $\mathbf{3 0}$ \\
BRAF/RAS Mutations* & Number of Specimens \\
WT/WT & 10 \\
BRAF $600 \mathrm{E} / \mathrm{KM}$ & 10 \\
NRAS/HRAS & 9 \\
BRAF/K/R,G12D & 1 \\
\hline
\end{tabular}

"See Supplementary Table 2 for more information regarding the presence of other cancer genes.

\section{SAB298 inhibits SRC-family kinases, ERBB2 and PIK3R}

We performed radioisotope filtration binding assay [10] that showed high affinity of SAB298 to several SRCfamily kinases (SFK), such as YES1, BLK, LCK, FGR, $\mathrm{HCK}$ and $\mathrm{FYN}\left(\mathrm{IC}_{50}\right.$ ranging from $\left.0.7-21.7 \mathrm{nM}\right)$, but very little to BRAF, RAF1, ARAF, ABL1, ABL2, WEE1 and ERBB2 $\left(\mathrm{IC}_{50} 1,200->10,000 \mathrm{nM}\right)$, or to IGF1R and CDK4/ cyclin D1 $\left(\mathrm{IC}_{50}>10,000 \mathrm{nM}\right)$ (Supplementary Table 3). Furthermore, we applied the in situ KiNativ ${ }^{\circledR}$ screening test that confirmed the kinase selectivity of SAB298 against several SFKs $\left(\mathrm{IC}_{50}<10-60 \mathrm{nM}\right)$ including SRC, YES1, LYN, and CSK, and against ABL2, and the receptor kinases ERBB2 and ERBB3, with some variability between the two cell lines tested (YUSIV and YUSIK, Table 2). The $\sim 10$-fold and $\sim 20$-fold higher binding affinity of SAB298 to SRC and ERBB2 in the in situ KiNativ ${ }^{\mathrm{B}}$ assay compared to the radioisotope filtration binding assay done on purified compounds indicated stronger activity with the native conformation in the cellular milieu. There was very little activity against mTOR, EGFR, LCK and MEK1 ( $\mathrm{IC}_{50} 1,300-2,900 \mathrm{nM}$, Table 2).

We confirmed that SAB298 inhibits SFK by probing with anti-IEDNEpYTAR antibodies for autophosphorylated Y416 (pY416). Melanoma cell lines displayed variable levels of basal pY416, which was consistently suppressed by SAB298 (Figure 4, pY416 SFK). In addition, SAB298 suppressed PI3K, the SRC downstream signaling target [11] observed by decrease in phospho-Y467/199 PIK3R1/3 (Figure 4, pY467/199 PIK3R1/3). Interestingly, there was a correlation between the levels of pY416 SFK and pY467/199 PIK3R; cells that had very low or undetectable levels of pY416 SFK also displayed low or undetectable levels of pY467/199 PIK3R (Figure 4, YUSEEP, YUSIK and YUKIM). However, the basal levels of pY416 SFK or pY467/199
PIK3R were not markers for the sensitivity to the compound (Figure 4, compare the highly resistant 501 mel, YUGASP and YUROB to the sensitive YUSIV, YUSIK and YUSEEP, $\mathrm{IC}_{50}$ and AUC shown on the bottom of each lane). In addition, the cell lines expressed different levels of SFK members, SRC, LYN, FYN and YES (Figure 4, as indicated), that may have a role in drug response.

We performed short hairpin RNA (shRNA) knockdown of SRC, LYN, YES, and FYN to identify the "addictive" SFK (Figure 5). The results show that SRC depletion in YUSIV, YUSIK and YUGASP melanoma cells induced growth arrest whereas 501 mel cells were not affected (Figure 5A). YUSIV melanoma cell line, the most sensitive to inhibition by SAB298, required LYN for optimal cell proliferation (Figure 5B), whereas there was only at most $50 \%$ reduction in growth in response to downregulation of YES and FYN (Figure 5B, 5C). Here again, the most resistant were $501 \mathrm{mel}$ melanoma cells (Figure 5D).

\section{SAB298 stimulates rather than inhibits MAPK signaling}

Time-course analysis revealed that treatment with SAB298 increased, rather than decreased, the levels of phospho-MEK S217/221 and phospho-ERK S217/221 (pERK T202/Y204). This effect was observed within 2-6 hours and was maintained throughout the 72 hours incubation with the inhibitor (Figure 6A). This unexpected long term signaling response was observed in YUSIV that carries PDE8A-RAF1 fusion protein and in $B R A F^{\mathrm{V} 600 \mathrm{E}}$ mutant melanomas (501 mel and SK-MEL-28). A similar response was observed in seven additional melanoma cell lines regardless of the presence or absence of $B R A F$ or NRAS oncogenic mutations (Figure 6B). In all cases, there was either an increase in pERK Thr202/Tyr204 or no 
effect, especially when the levels of basal pERK Thr202/ Tyr204 were high (Figure 6B and Figure 7A). RAF activity was required to maintain $\mathrm{pERK}$ because the RAF1-dimer inhibitor BGB-283 abolished pERK (Figure 6C).

We examined if the "paradoxical" activation of the MAPK pathway is a common response to SRC inhibition in these melanoma cells. Side-by-side comparison of SAB298 and UM-164 confirmed that the two inhibitors downregulated pSFK Y416, but had an opposite effect on pERK T202/Y204 (Figure 7A). Additionally, in contrast to UM-164, SAB298 induced p38 T180/Y182 phosphorylation within two hours, in a manner similar to that of pERK T202/Y204 stimulation (compare Figure $7 \mathrm{~B}$ to Figure 6A), but this effect subsided after $\sim 24 \mathrm{hrs}$ (Figure 7B). The results were not due to aberrant p38 response in these melanoma cells, because the MEK $1 / 2$ inhibitor trametinib effectively abolished pp38 T180/ Y182 (Figure 7C). The p38 kinase inhibitors ralimetinib and LY2228820 had little effect on melanoma cells $\left(\mathrm{IC}_{50}>10,000 \mathrm{nM}\right.$ data not shown), suggesting that this kinase does not carry a critical role in melanoma cell proliferation as it does for triple-negative breast cancer cells [6]. Altogether, we show that the SFK-inhibitor SAB298 is a potent suppressor of melanoma cell proliferation independent of $\mathrm{pERK}$ activity.

\section{SAB298 inactivates MAPK phosphatases via inhibition of ERBB2}

The SAB298 induced MAPK activation was not the direct effect of SFK inhibition because it was not observed in response to knockdown of SRC, YES or FYN
A

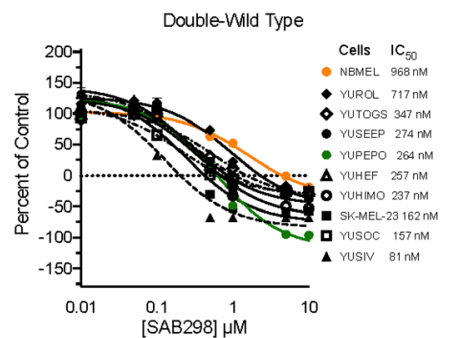

D

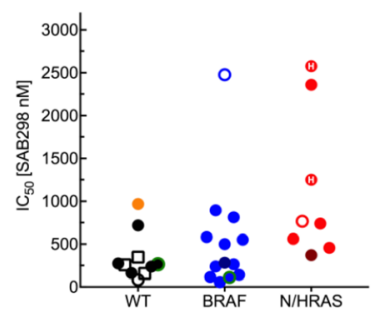

G

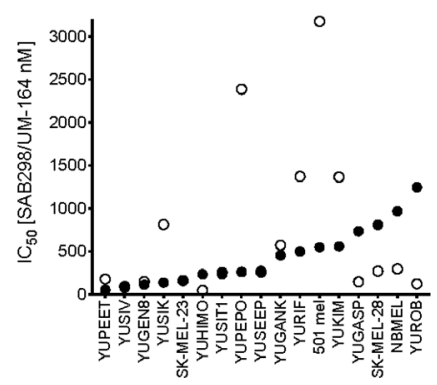

B
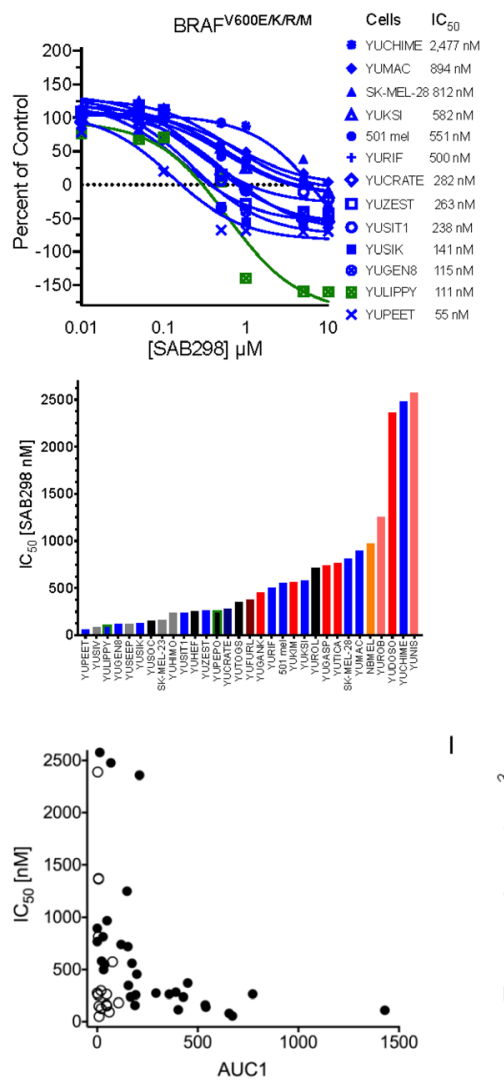

I
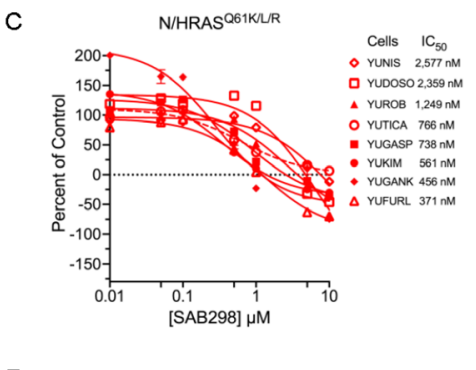

$\mathrm{F}$
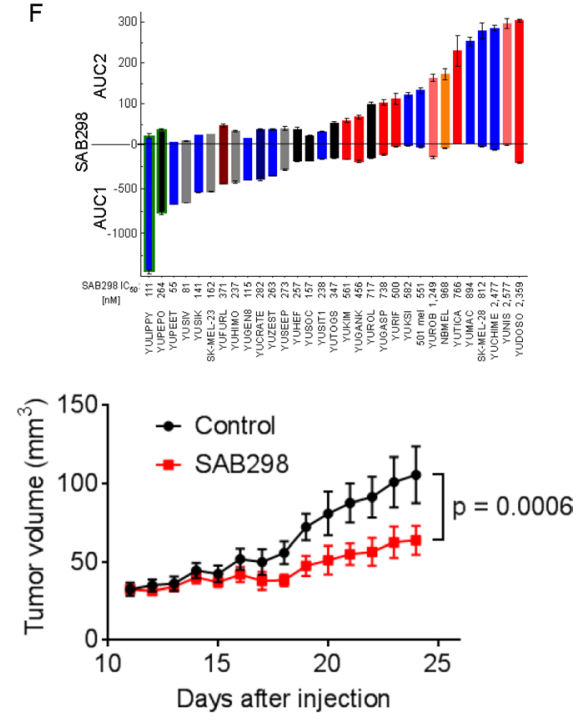

Figure 2: Suppression of cell proliferation in response to SAB298 and UM-164. The results show CellTiter-Glo ${ }^{\circledR}$ Luminescent Viability Assay and the values are average of triplicate or quadruplet wells, displayed as percent of control assessed at the end of 72 hours treatment \pm SE. (A-C) Growth arrest in response to SAB298. The legends on the right provides the $\mathrm{IC}_{50}$, i.e., drug concentrations that reduced cell viability to 50\% of the control generated in GraphPad Prism. Black, blue and red lines indicate melanoma cells that are wildtype for BRAF or NRAS (double-wild type), $\mathrm{BRAF}^{\mathrm{V} 600 \mathrm{E} / \mathrm{K}}$, or NRAS/HRAS ${ }^{\mathrm{Q} 61}$ mutants, respectively. Green lines indicate ocular melanoma cells with GNA11 ${ }^{\mathrm{Q} 209 \mathrm{~L}}$, broken lines are NF1 ${ }^{\text {null }}$ (---) broken dot broken line are RAC1 ${ }^{\mathrm{P} 29 \mathrm{~S}} / \mathrm{NF} 1^{\text {null }}$ double mutant (-.-), and orange line indicates normal human melanocytes that are wild type for all mutations. STDV was about 5\% of total count. (D-F) show aligned dot-plot of SAB298 IC S0 $_{50}$ values, bar graph of increasing levels of IC ${ }_{50}$ and AUC (Area Under the Curve). Color code as in (A-C). Grey bars indicate melanoma with fusion genes and $(\mathrm{H})$, indicates $\mathrm{HRAS}^{\mathrm{Q} 61 \mathrm{~K}}$ mutation. (G and $\mathbf{H}$ ) show comparisons between SAB298 (O) and UM-164 $\mathbf{O}$ in $\mathrm{IC}_{50}, \mathrm{AUC1}$. (I) Tumor growth in response to SAB298. YUSIK tumor bearing mice were treated daily with intraperitoneal injection of $20 \mathrm{mg} / \mathrm{kg} \mathrm{SAB} 298$ (red) starting on day 12 after injection or with solvent as control (blue). Data are average of 6 mice \pm SEM. The $p$-value of 0.0006 was calculated by Uncorrected Fisher's LSD using GraphPad based on the last day data. NBMEL; OOO NF1; $\square$ NF1 and $\mathrm{RAC1}$; O GNA11 ${ }^{\mathrm{Q} 209 \mathrm{~L}}$; NRAS ${ }^{\mathrm{G} 12 \mathrm{D}} ; \mathrm{BRAF}^{\mathrm{G} 469 \mathrm{~A}}$. 
(Supplementary Figure 3). We therefore explored the role of two MAPK phosphatases, PP2A (encoded by PPP2CA) and SHP2 (encoded by PTPN11) [12-14]. Probing with antibodies to the inactivated PP2A (phospho-PP2A Y307) [15], showed increase in the levels of inactivated PP2A levels in response to SAB298, in a way similar to that of okadaic acid, a potent inhibitor of these protein phosphatases (Figure 8A, pPP2A Y307). In addition, SAB298 inactivated phospho-SHP2 Y542 in YUSIK, YUROB and YUSOC melanoma cell lines, but not in YUGASP (Figure 8B, 8C). The general levels of pSHP2 Y542 was inversely proportional to the levels of pERK (compare Figure 8 to Figure 6B).

Because SHP2 activity is modulated by receptor tyrosine kinases [16], we tested if ERBB2 inhibition, an additional in situ target of SAB298 (Table 2), is the cause of this process. The results confirmed that SAB298 suppressed phospho-ERBB2 Y1196 (Figure 8C and 8D, YUSOC, YUROB, YUSIV, YUTOGS). Interestingly, YUROB melanoma displayed extremely high levels of pERBB2 Y1196 that was abolished by SAB298 (Figure 8D). We concluded that pERK activation is the consequence of reduced PP2A and SHP2 activities, due to ERBB2 inhibition by SAB298. However, inhibition of ERBB2 with the potent ERBB2/ERBB3 inhibitor sapitinib, or with anti-ERBB3 antibody MM121, had very little effect on cell proliferation (YUSIV and YUSIK, $\mathrm{IC}_{50}$ $>10,000 \mathrm{nM}$ ), while the EGFR/ ERBB2/ ERBB4 inhibitor dacomitinib had somewhat better inhibitory effect $\left(\mathrm{IC}_{50}\right.$ 1,200 $\mathrm{nM}$ and 2,600 $\mathrm{nM}$, respectively), suggesting that ERBB2 is not directly involved in SAB298 induced growth arrest.

\section{SAB298 downregulates MITF}

We examined the long-term effects of SAB298, such as the expression of cyclin D1, MYC, p27 ${ }^{\mathrm{CIP}}$, and p53, but did not observe any consistent shared response (data not shown). On the other hand, we checked the impact of ERK activation on MITF (melanogenesis associated transcription factor) because MITF is a critical transcription factor for melanocyte and melanoma cell proliferation [17], whose stability is reduced when phosphorylated by MAPK or KIT $[18,19]$. The results showed that SAB298 suppressed MITF levels in four out of seven melanoma cell lines (YUSIV, YUSIK, SK-MEL-28 and YUKIM), but not in YUPEET, YUSEEP and $501 \mathrm{mel}$ cells (Figure 9A). However, there was no correlation between $\mathrm{IC}_{50}$ levels and MITF downregulation (Figure 9A, indicated on the bottom for each cell line), suggesting that melanoma cells differ in their dependence on MITF.

The ERK-inhibitor SCH772984 validated the role of the kinase activity in downregulating MITF. Incubation with SCH772984 increased the basal levels of the transcription factor in YUSIV and abolished its downregulation by SAB298 in both YUSIV and YUSIK melanoma cells (Figure 9B). Furthermore, the addition of the proteasome inhibitor MG-132 (20 $\mu \mathrm{M}$ for $24 \mathrm{hrs}$ ) abolished SAB298 impact on MITF (Figure 9C), in agreement with published reports showing that the phosphorylated transcription factor is a target to proteasome degradation $[18,19]$. In contrast to SAB298, UM-164 increased MITF levels (Figure 9D) as a consequence of ERK inhibition (Figure 7A).

We tested if modulation of MITF had a physiological effect as it can impact the expression of melanocytespecific genes, such as tyrosinase. We show that indeed, SAB298 suppressed the levels of tyrosinase in melanoma cells that express the protein (Figure 9E, YUSIK, YUKIM and YUPEET), suggesting that downregulation of this transcription factor can contribute to SAB298 inhibition of cell proliferation in some cell lines.

\section{DISCUSSION}

Targeting SRC in melanoma has been of interest for over a decade [20]. Published results with three melanoma cell lines showed that dasatinib and bosutinib had a minor
A

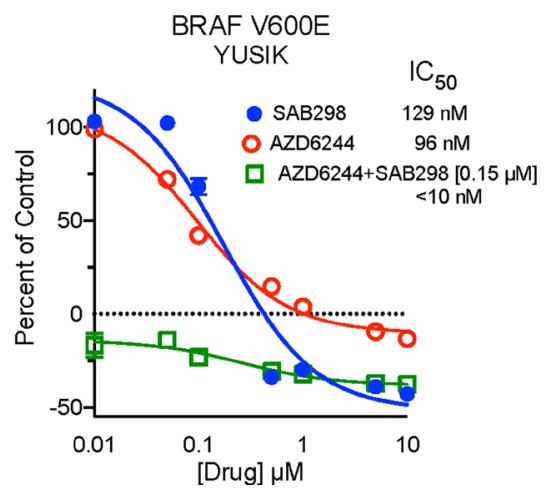

B

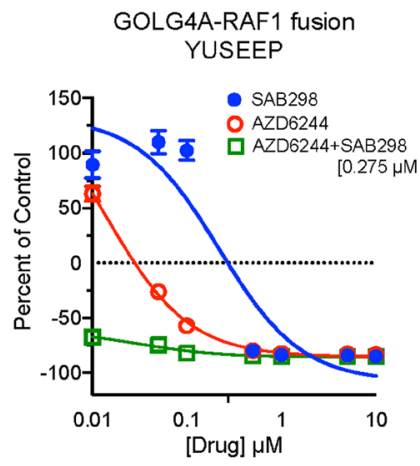

C

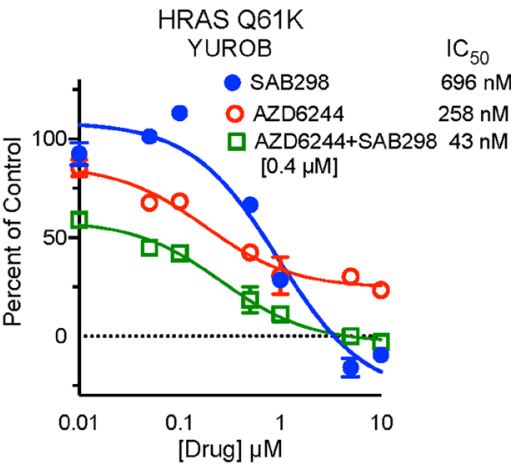

Figure 3. Synergistic Inhibition of BRAF ${ }^{\mathrm{v} 60 \mathrm{E}}$ Melanoma Cell Proliferation by Treatment with SFK and MEK Inhibitors. Cell proliferation of YUSIK, $501 \mathrm{mel}$ and YUROB melanoma cell lines (A, B and C, respectively) in response to SAB298 (blue), AZD6244 (red), and AZD6244 plus SAB298 (green). SAB298 was added to AZD6244 at $0.15 \mu \mathrm{M}$ (YUSIK), or $0.4 \mu \mathrm{M}$ (501 mel and YUROB). The $\mathrm{IC}_{50}$ for each drug alone and in combination are indicated in the legend for each cell line. 
Table 2: KiNativ ${ }^{\mathrm{TM}}$ assay tests for SAB298 target protein*

\begin{tabular}{lcc}
\hline Kinase & YUSIV & YUSIK \\
\hline YES1 & $<10$ & Not Present \\
SRC & 31 & Not Present \\
LYN & 60 & 190 \\
ABL2 & 87 & 240 \\
ERBB3 & 290 & 240 \\
MEK5 & 370 & 1500 \\
CSK & 420 & 910 \\
ERBB2 & 410 & 530 \\
mTOR & 1,300 & 2,000 \\
EGFR & 1,300 & 530 \\
LCK & 1,400 & Not Present \\
RIPK2 & Not Present & 20 \\
MEK1 & 2,900 & Not Present \\
\hline
\end{tabular}

${ }^{*}$ The results show $\mathrm{IC}_{50}$ in $\mathrm{nM}$. Values were determined from 3-point dose response curve.

impact $\left(\mathrm{IC}_{50} 1,300-10,000 \mathrm{nM}\right)$ [20], and in another case, dasatinib did not have an effect on cell proliferation, but inhibited migration and invasion [21]. Additional studies showed that SRC-I1 (SRC inhibitor-1) was inactive on patient-derived $\mathrm{BRAF}^{\mathrm{V} 600 \mathrm{E}}$ mutant melanoma cells resistant to vemurafenib, but enhanced the activity of the pan-RAF inhibitor TAK632 against these cells [22]. Furthermore, phase 2 clinical trials with dasatinib and saracatinib had minimal clinical activity as a single agent in patients with advanced melanoma [23], and response rate to dasatinib among melanoma patients with KIT activating mutation was low [24]. This is in contrast to the highly efficient effect of dasatinib in BCR-ABLdriven diseases such as chronic myeloid leukemia (CML) and Philadelphia-chromosome-positive acute lymphoblastic leukemia ( $\mathrm{Ph}+\mathrm{ALL})$, characterized by the constitutively active tyrosine kinase, BCR-ABL [25].

We described a new compound, SAB298, that binds to the ATP kinase domain of several SFKs, and inhibits melanoma cell proliferation in vitro and in vivo, and affects other cancer cell types as well (lymphoblastic leukemia, carcinoma, astrocytoma) regardless of oncogene expression. The compound has multiple targets, the SFK family members and ERBB2/3, but has very little activity against BRAF, RAF1, ARAF, IGF1R or CDK4/ Cyclin D1. It is common for kinase inhibitors to target more than one protein. For example, dasatinib inhibits $\mathrm{SRC}$, c-Kit, ephrin receptors and $\mathrm{BCR} / \mathrm{Abl}$; imatinib targets ABL, KIT and PDGFR; SU6656 targets SRC family kinases and BRSK2, AMPK, Aurora C, Aurora B, CaMKK $\beta$; and bosutinib and saracatinib inhibit SRC and ABL kinases. Quantitative analysis of 178 commercially available kinase inhibitors against a panel of 300 recombinant protein kinases revealed a wide spectrum of promiscuity and identified multitargeted inhibitors of specific, diverse kinases [26], indicating that SAB298 is not more promiscuous compared to other kinase inhibitors.

Our studies included 30 different patient-derived melanoma cell lines well characterized for mutations and genomic aberrations. Although double-wild type (BRAF/NRAS) melanoma cells were the most sensitive to the compound (with $\mathrm{IC}_{50}$ below $400 \mathrm{nM}$ ), the BRAF ${ }^{\mathrm{V} 600}$ mutant cells included a group of highly responsive and less responsive melanoma cells $\left(\mathrm{IC}_{50}\right.$ below $400 \mathrm{nM}$ and above $500 \mathrm{nM}$, respectively). Melanoma cells with oncogenic NRAS were the least sensitive $\left(\mathrm{IC}_{50}\right.$ above 400 $\mathrm{nM})$. On the other hand, alterations in NF1, including early termination, were not sufficient to raise the resistance of double-wild cells, such as YUSOC ( $\left.\mathrm{IC}_{50} 157\right)$, YUHEF $\left(\mathrm{IC}_{50} 257, \mathrm{NF} 1 \mathrm{pQ} 853 \mathrm{X}\right)$ and YUTOGS $\left(\mathrm{IC}_{50} 347, \mathrm{NF} 1\right.$ p.W336X/E337K), or cells carrying the fusion protein PDE8A-RAF1 YUSIV ( $\mathrm{IC}_{50} 81$ nM, NF1 p.L626F), but may had an impact on one $\mathrm{BRAF}^{\mathrm{V} 600 \mathrm{~K} / \mathrm{M}}$ melanoma (YUCHIME) displaying extreme resistance $\left(\mathrm{IC}_{50} 2,477\right.$ nM, NF1 p.K1714N). There was high correlation between the levels of pSFK and pPIK3R1/3, but the variability between the cellular responses did not correlate with the phosphorylated levels of these markers, and pSFK intensity levels did not correlate with the presence or absence of a melanoma oncogene. Interestingly, knockdown expression revealed that melanoma cells sensitive to the compound are "addicted" to SRC and LYN activity.

We explored the long term effects of SAB298. The substance induced caspase activity and apoptosis, regardless of p53, MYC, p27KIP and cyclin D1 expression (data not shown). On the other hand, we identified in about $57 \%$ of the cell lines, a potent and unique SAB298 function of downregulating MITF, a lineage-transcription factor for melanocytes and melanomas. We demonstrated that 
downregulation of MITF is the consequence of a known pathway, in which MAPK activation phosphorylates the transcription factor and targets it to degradation [27]. In contrast, UM-164 inhibited ERK and caused activation of MITF, an effect that may reduce the long term impact on cell proliferation and contribute to the development of drug resistance as described for BRAF- and MEK inhibitors [28]. Analysis of biopsies from $B R A F^{V 600 E}$ melanoma patients following relapse with vemurafenib, or combination of dabrafenib and trametinib revealed upregulation of several lineage-specific transcription factors including MITF [29]. The increased levels of
MITF in response to inhibition of MAPK was observed within the first two weeks of treatment [30]. Furthermore, the melanoma cells from tumor-bearing mice treated with vemurafenib were more tolerant to BRAF inhibition than cells isolated from untreated tumors [30], and the protease inhibitor nelfinavir mesylate suppressed MITF expression and sensitizes BRAF and NRAS mutant melanoma to MAPK inhibitor treatment. In another study, in vitro and in vivo studies with the $\mathrm{CH} 6868398$, demonstrated that reduction of MITF levels increased the response to the BRAF inhibitor PLX4720 [31]. Altogether, our data show that one possible cause for resistance to SRC-inhibitors is

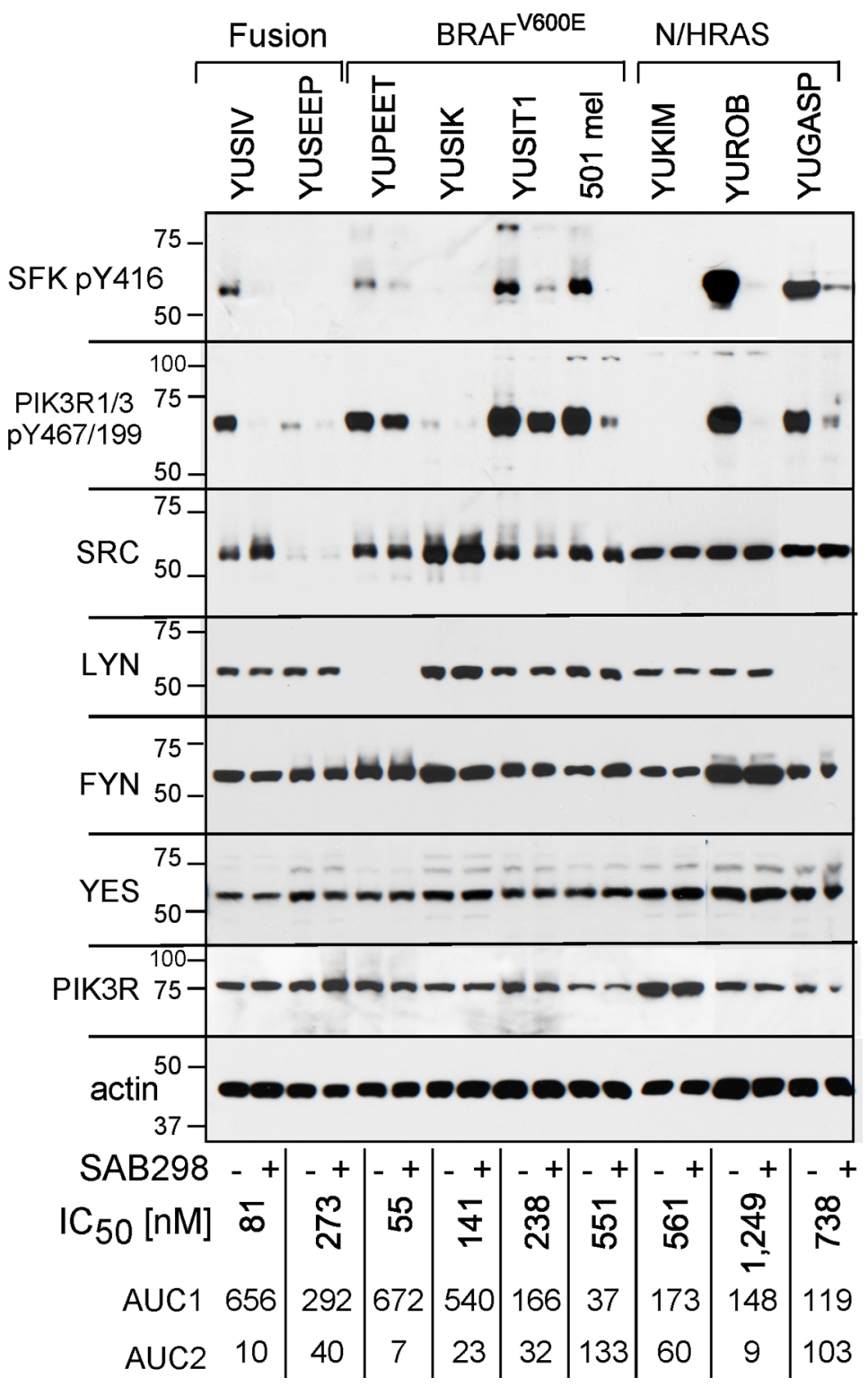

Figure 4: SAB298 suppresses SFK and PI3K activities. Western blot analyses of melanoma cells treated with DMSO or SAB298 $(0.5 \mu \mathrm{M})$ for $5 \mathrm{hrs}$. Cell extracts were probed with antibodies to phosphorylated SFKs (SFK pY416), phosphorylated PI3KR1/3 (pY467/199), to different SFKs or PIK3R as indicated. Reduction in the levels of pSFK Y416 in response to SAB298 indicates inhibition of SFK. Two cell lines (SK-MEL-28 and YUSEEP) did not express detectable levels of SFK pY416. Anti-actin represents protein loading. The levels of growth responses to SAB298 are indicated by the $\mathrm{IC}_{50}, \mathrm{AUC1}$ and $\mathrm{AUC2}$ on the bottom of each lane. YUSIV and YUSEEP carry PDE8A-RAF1 or GOLGA4-RAF1 fusion proteins, respectively. 
A

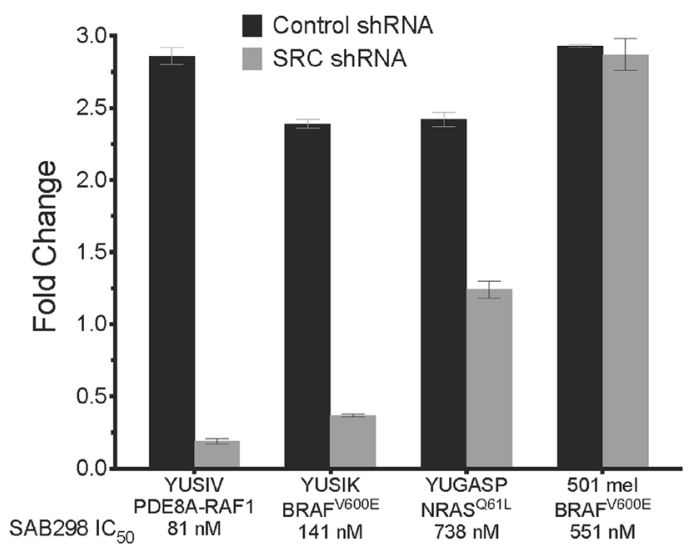

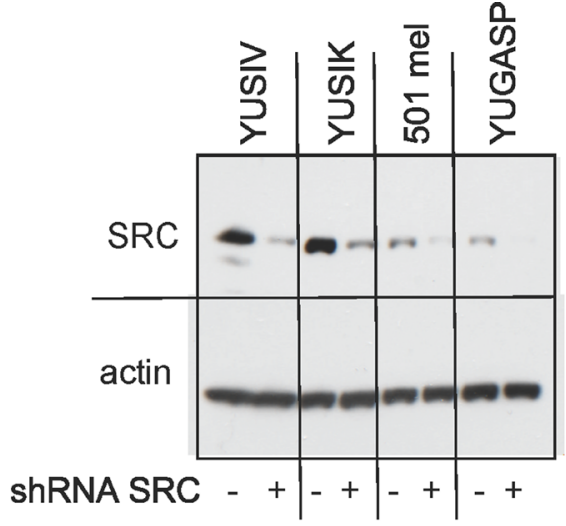

B

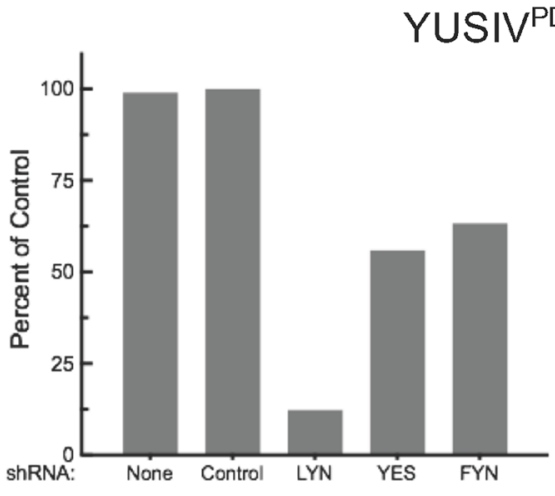

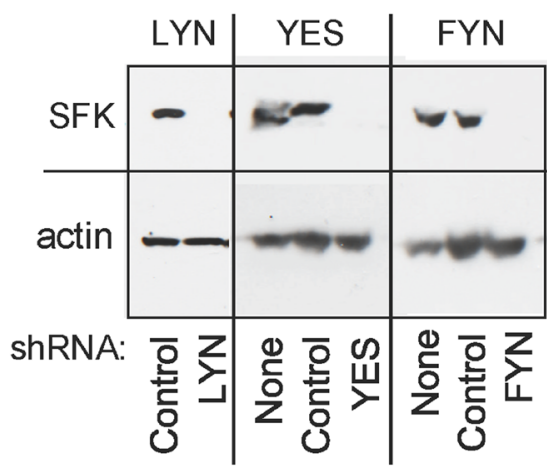

C

YUSIK BRAFV600E
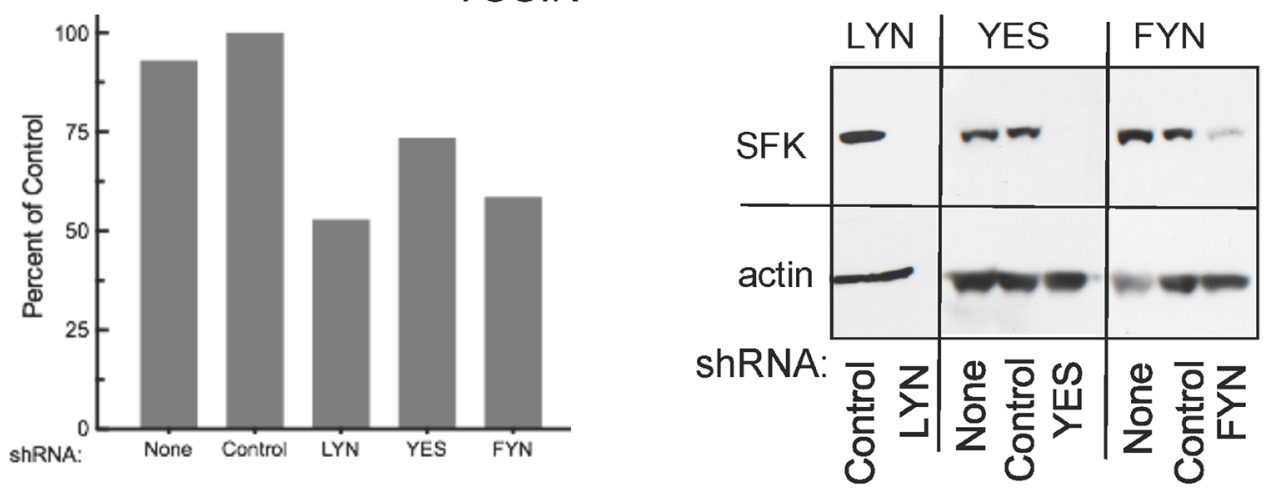

D

501 mel BRAFV600E
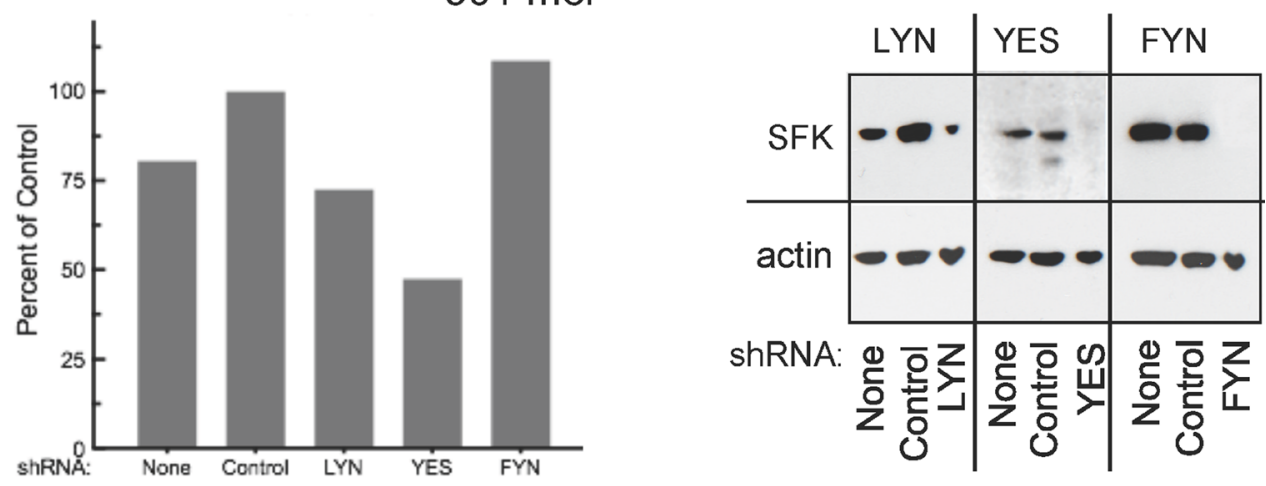

Figure 5: Cell proliferation in response to downregulation of specific SFKs. The histograms show cell proliferation of melanoma cells infected with shRNA targeting SRC, LYN, YES or FYN compared to none-infected cells (None) and control shRNA (Control) (left panels A-D). The shRNA knockdown was validated by western probing for the expression of the SFK employing the respective antibodies (right panels A-D). SFK: SRC Family Kinase. 
the increase in MITF, a problem that is not reproduced by SAB298 (summarized in Figure 10).

\section{MATERIALS AND METHODS}

\section{SAB298 and other SRC-kinase inhibitors}

SAB298 was synthesized in six steps according to the procedures outlined in WO 2018/049127 patent application (examples $3,15,17,44,45$ and 46 ). Its activity was compared to UM-164 (Sigma-Aldrich, St. Louis, MO), dasatinib (BMS 354825), bosutinib (SKI-606), saracatinib, SU6656, sapitinib (AZD8931), ralimetinib (LY2228820), dacomitinib, lifirafenib (BGB-283) and SCH772984 (all from Selleckchem, Houston, TX), okadaic acid (MilliporeSigma, St. Louis, MO), trametinib (LC Laboratories, Woburn), and imatinib (NCI).

\section{Growth responses and apoptosis}

SFK-inhibitors were tested on a panel of NCI-60 cell lines (Supplementary Table 1) and 30 melanoma cell lines and NBMEL, i.e., normal human melanocytes isolated from a newborn foreskin (Table 1 and Supplementary Table 2). The Yale melanoma cohort designated $Y U$ originated from tumors excised to improve patient quality of life and used with participants' informed consent according to Health Insurance Portability and Accountability Act (HIPAA) regulations with Human Investigative Committee protocol.

The melanoma cells were grown in OptiMEM (Invitrogen, Carlsbad, CA) supplemented with 5\% fetal calf serum and antibiotics. The normal human melanocytes (NBMEL) were grown in medium supplemented with bFGF, IBMX and dbcAMP [32]. Most of the Yale melanoma cell lines were characterized by next-generation sequencing $[7,33]$ (Supplementary Table 2).

Cell proliferation was measured with the CellTiterGlo $^{\circledR}$ Luminescent Cell Viability Assay (Promega Corporation, Madison, WI). Melanoma cells were seeded in 96-well plates in triplicate or quadruplet wells, with increasing concentrations of kinase inhibitors for $72 \mathrm{hrs}$. The rate of proliferation was also tested after knockdown of different SRC-family kinases (SFK) with hairpin lentivirus shRNA as indicated. The $\mathrm{IC}_{50}$ (the dose that elicits 50\% inhibition compared to vehicle control)

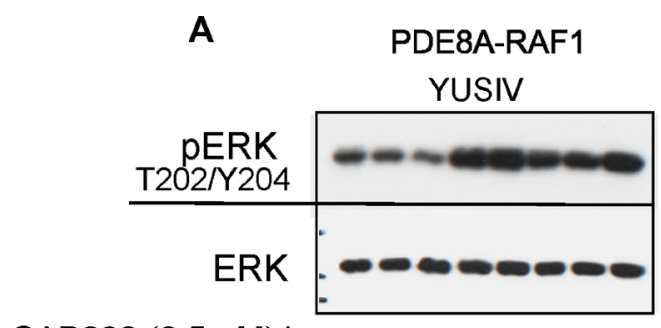

SAB298 $(0.5 \mu \mathrm{M}) \mathrm{hrs} 012615244872$

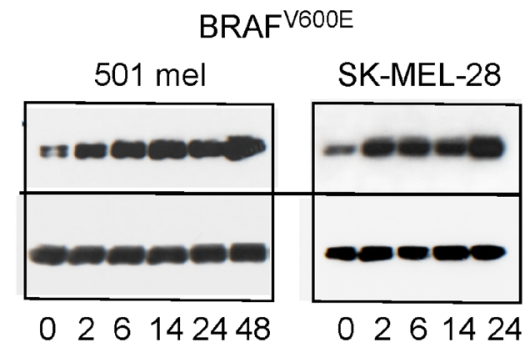

0261424
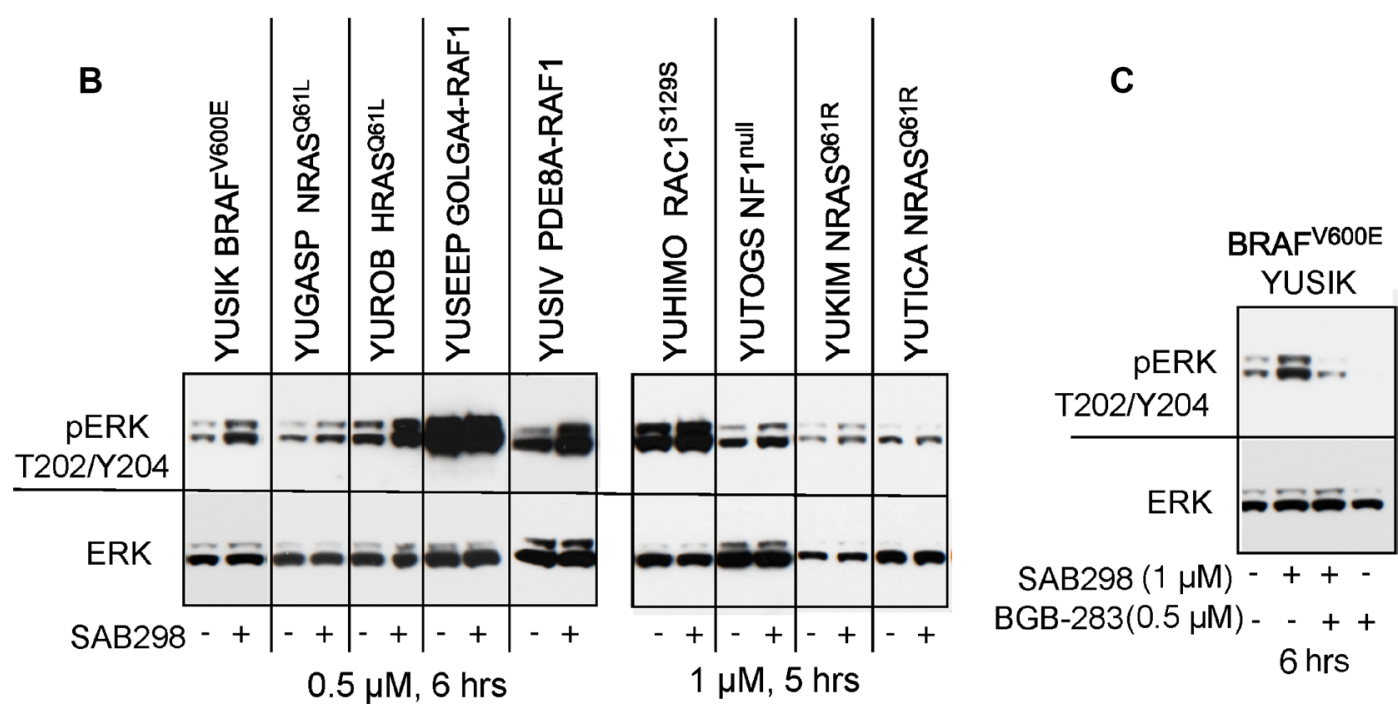

Figure 6: MAPK signaling is activated in response to SAB298. Melanoma cells were treated with $\mathrm{SAB} 298(0.5 \mu \mathrm{M}$ or $1 \mu \mathrm{M}$, as indicated) and harvested at increasing time points (A), or after 5-6 hours $(\mathbf{B}, \mathbf{C})$. The panels show western blots probed with antibodies to phosph-ERK1/2 Thr202/Tyr204 mAb (pERK), ERK1/2 (ERK), phospho-MEK1/2 (pMEK), and actin as protein loading control. (C) Cells were treated with SAB298, BGB-283 (a RAF-dimer inhibitor), or both for 6 hrs to validate the role of RAF kinase in ERK phosphorylation. The mutation status of each cell line is indicated on the top. 
and AUC (area under the curve) were calculated from the slope of the drug response by linear interpolation employing GraphPad Prism 7 software [32]. The statistical significance of synergism of response to drug combinations was evaluated by following Chou and Talalay algorithm [8, 9]. See also details in Supplementary Material.

The rate of apoptosis was measured using the Dead Cell Apoptosis Kit with Alexa Fluor ${ }^{\circledR} 488$ annexin V and propidium iodide (Invitrogen, V13241). Phosphatidylserine was visualized by flow cytometry following the manufacturer's instructions. The assay was done in response to SAB298 $(0.5 \mu \mathrm{M}$ and $1 \mu \mathrm{M}, 24 \mathrm{hrs})$, compared to DMSO (negative control) or camptothecin $(10 \mu \mathrm{M})$, as a positive control. In addition, we used the 96well colorimetric Caspase 3 Assay kit (Millipore Sigma) to measure caspase activity in response to increasing concentrations of SAB298, and western blotting for apoptotic markers, such as cleaved PARP.

\section{Screening of SAB298 cellular targets}

The effect of SAB298 on a panel of 36 recombinant kinases, was screed with the radioisotope filter binding assay [10, 26] employing 10 concentrations of the compound with $10 \mu \mathrm{M}$ ATP (Reaction Biology Corporation, Malvern, PA). In addition, we tested the endogenous kinome response to $\mathrm{SAB} 298(0.05 \mu \mathrm{M}, 0.5 \mu \mathrm{M}$ and 5 $\mu \mathrm{M}$ ) in lysates from two melanoma cell lines (YUSIV and
YUSIK) employing the KiNativ ${ }^{\circledR}$ platform [34] (ActivX Biosciences Inc., La Jolla, CA). KiNativ ${ }^{\circledR}$ is a robust, high performance mass spectrometry $\left(\mathrm{LC}-\mathrm{MS}^{2}\right)$ assay that uses biotinylated probes to measure relevant changes in the affinity to the ATP-binding sites of 205 native kinases as a function of cellular context [34]. We also validated SAB298 effect on the activity of SRC-family kinases by probing for phosphorylated Y416, the marker of activated SFKs, with anti-IEDNEpYTAR antibodies (also known as Y419, \#2101, Cell Signaling Technology, Beverly, MA). In some cases the cells were incubated overnight with 20 $\mu \mathrm{M}$ proteasome inhibitor MG-132 (CAS 133407-82-6, Millipore Sigma, Burlington, MA) to rescue degradation.

\section{SFKs-knockdown with short hairpin RNA (shRNA)}

We used puromycin-bearing lentiviral vectors pLKO.1 shRNA targeted to SRC, YES, LYN and FYN to test the effects of downregulation of specific kinases on cell proliferation and signal transduction, employing empty vector SHC001 as a negative control (MISSION, SigmaAldrich, Supplementary Table 4). The plasmids were packaged in lentiviral vectors with ViraPower ${ }^{\mathrm{TM}}$ Lentiviral Packaging Mix kit (Thermo Fisher, cat \#K497500), or with two packaging vectors psPAX2 and pMD2G, and transfected into $293 \mathrm{~T}$ cells. The medium was collected and filtered with Millex-GV 33 mm PVDF filter (Millipore
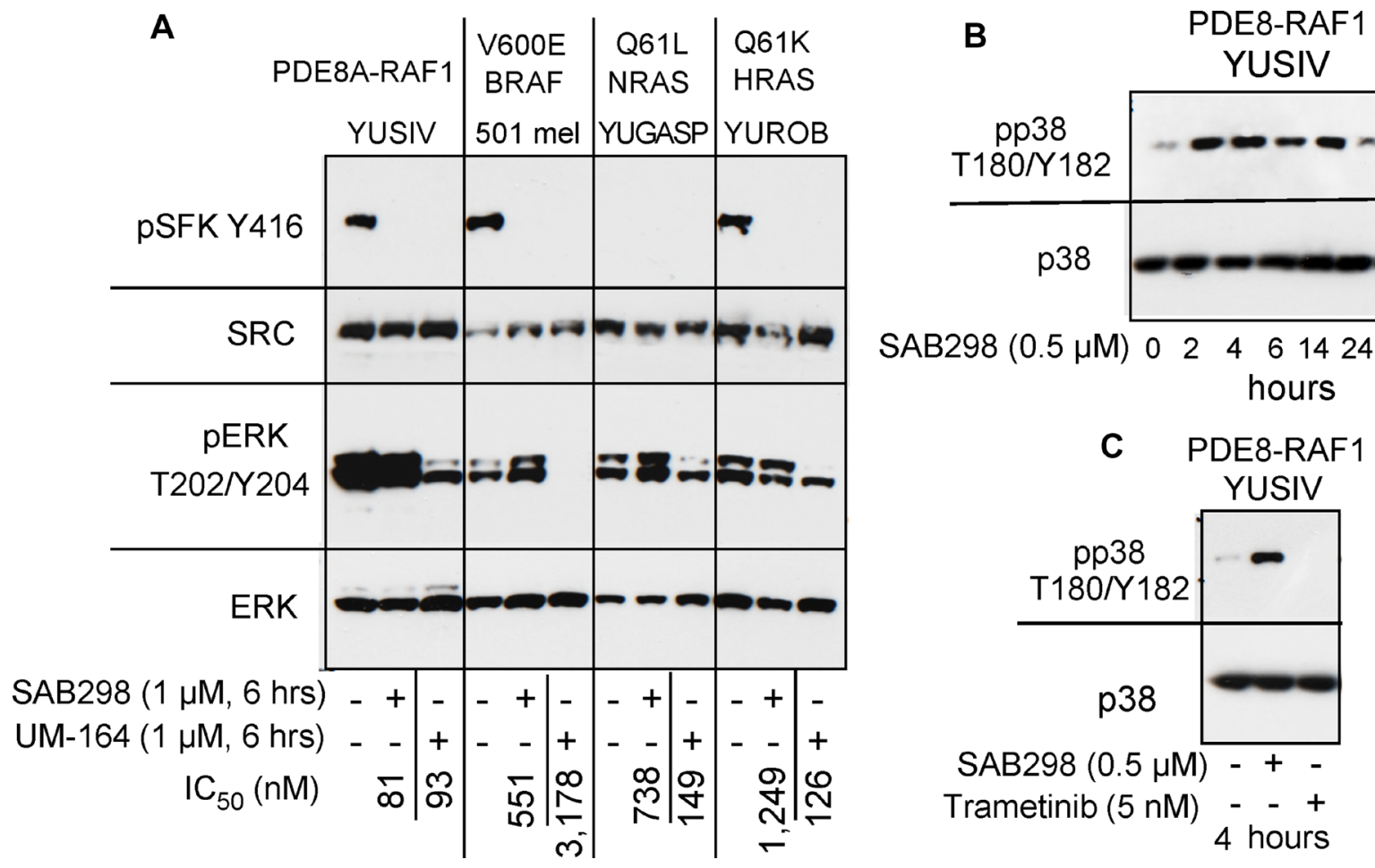

Figure 7: SAB298 and UM-164 inhibit SFK activity but have opposite effects on ERK and p38. (A) Western blot showing common inhibition of SFK (pSFK Y416) in YUSIV, 501 mel and YUROB melanoma cells in response to the two inhibitors, but pERK was inhibited only in response to UM-164 (pERK T202/Y204). (B) stimulation of pp38 T180/Y182 in YUSIV melanoma cells incubated for increasing periods of time with SAB298. (C) Trametinib, but not SAB298, inhibits pp38 T180/Y182. 
SLGV033RS) and then concentrated with Amicon Ultra-15 centrifugal filters (Millipore UFC910024). Melanoma cells were infected with the lentiviruses, selected with puromycin for two days, and three days later collected and processed for western blotting. In addition, the knockdown cells were seeded in 96-well plates and tested for cell proliferation in the absence and presence of puromycin with the CellTiter-Glo ${ }^{\circledR}$ Luminescent Cell Viability Assay, as described above.

\section{Western blotting and antibodies}

We used standard techniques to identify changes in intracellular signaling in response to various treatments [32]. Briefly, melanoma cells were incubated with test compounds, using DMSO as a control, collected by scraping on ice, and lysed in RIPA buffer supplemented with protease and phosphatase inhibitors (MA \#78428, and \#78425, respectively, Thermo Fisher Scientific, Waltham, MA). Protein concentrations were measured with the BioRad kit (Bio-Rad Laboratories, Hercules, CA), SDS sample buffer was added, extracts were heated at $95^{\circ} \mathrm{C}$, sonicated and centrifuged. Cell extracts $(20 \mu \mathrm{g} /$ lane) were fractionated in $3 \%-8 \%$ or $4-12 \%$ tris-acetate gel (NP0006, NuPAGE Life Technologies) [32]. We probed with the following primary antibodies: phosphoSRC Tyr416 (CST \#2101S), pSRC Tyr527 (\#2105), SRC (\#2108), pPI3K p85 Y458/p55 Y199 (\#4228), LYN (C13F9, \#2796), FYN (\#4023), phospho-MEK1/2 pSer217/221 (\#9121), MEK1/2, phospho-ERK2 pThr202/

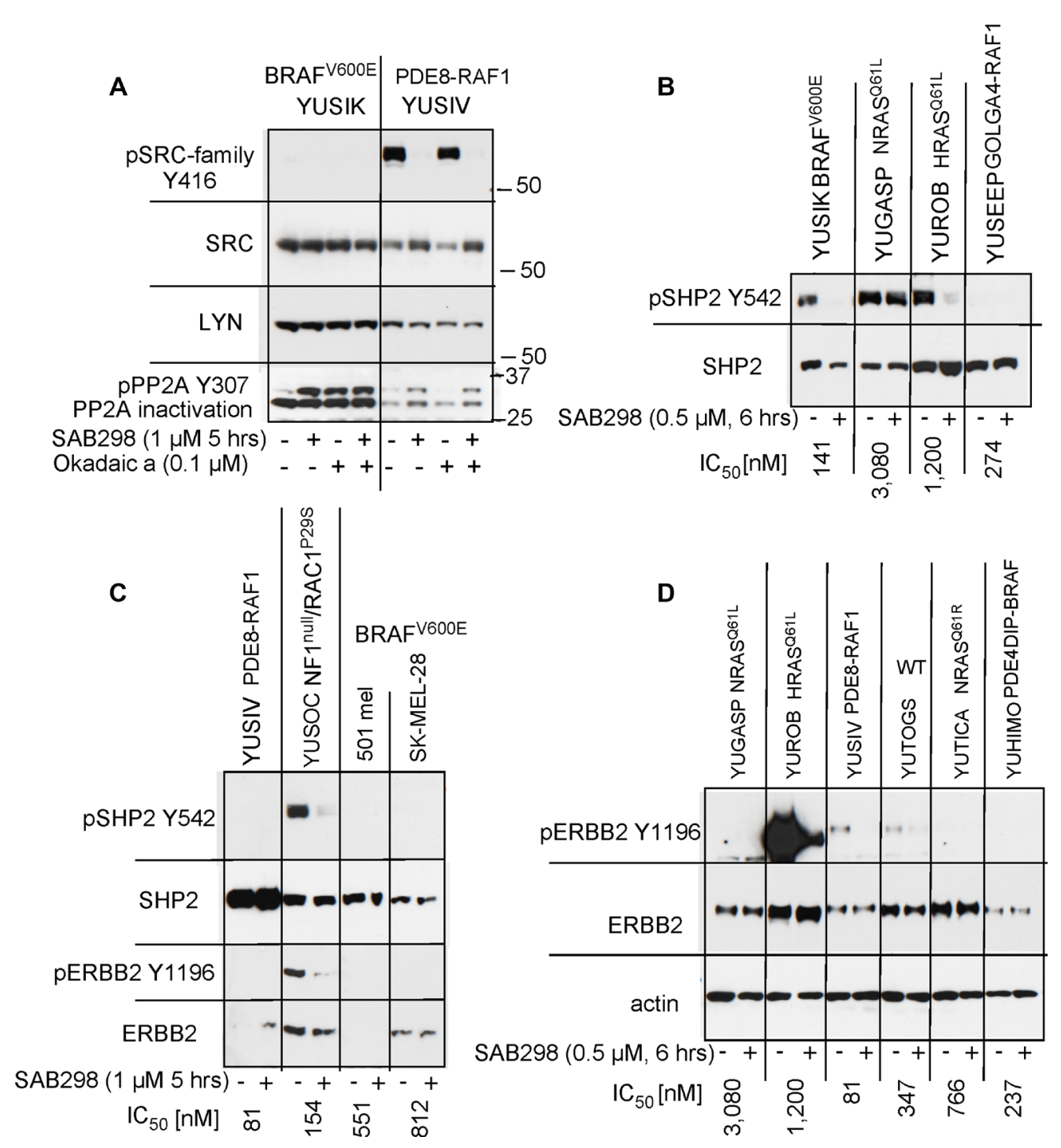

Figure 8: SAB298 inactivates PP2A, SHP2 via ERBB2 inhibition. (A) SAB298 increases the levels of inactivated PP2A (pPP2A Y307) in YUSIK and YUSIV melanoma cells in a fashion similar to okadaic acid (Okadaic a). Active (unphosphorylated) PP2A is not dependent on the presence of pY416 SFK. Panels B and C show SHP2 inactivation by SAB298 in YUSIK, YUROB and YUSOC, but not YUGASP melanoma cells (pSHP2 Y542). Suppression of SHP2 is associated with SAB298 induced inactivation of ERBB2 (pERBB2 Y1196) (C, D). 

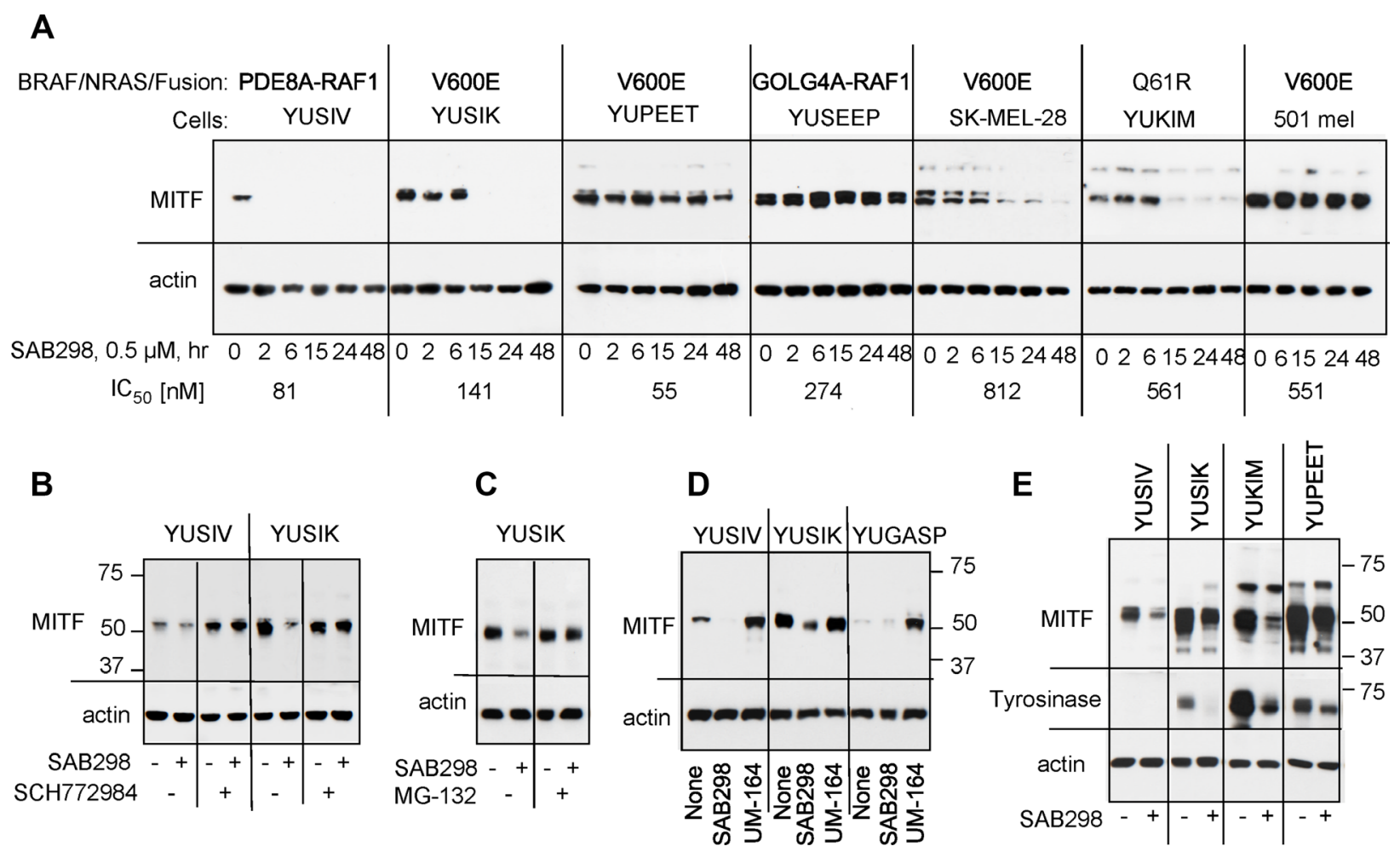

Figure 9: Suppression of MITF in response to SAB298. (A) MITF levels in melanoma cells incubated for increasing periods of times with SAB298 $(0.5 \mu \mathrm{M})$. The oncogenic status of each cell line is indicated on the top and the $\mathrm{IC}_{50}$ on the bottom of the panels. $(\mathbf{B})$ The MEK inhibitor SCH772984 $(0.5 \mu \mathrm{M})$ abolished SAB298 $(0.5 \mu \mathrm{M})$ induced suppression of MITF. Cells were harvested after 6 hrs treatment with the drugs. (C) The proteasomal inhibitor MG-132 (20 $\mu$ M, 24 hrs) suppressed MITF degradation in response to SAB298. (D) The SRC inhibitor UM-164 (1 $\mu \mathrm{M}, 6 \mathrm{hrs)} \mathrm{increases} \mathrm{MITF} \mathrm{expression.} \mathrm{(E)} \mathrm{Tyrosinase} \mathrm{levels} \mathrm{decrease} \mathrm{in} \mathrm{response} \mathrm{to} \mathrm{SAB298}(0.5 \mu \mathrm{M}$ for $20 \mathrm{hrs}$ ) due to downregulation of MITF.

\section{SFK Inhibitors}

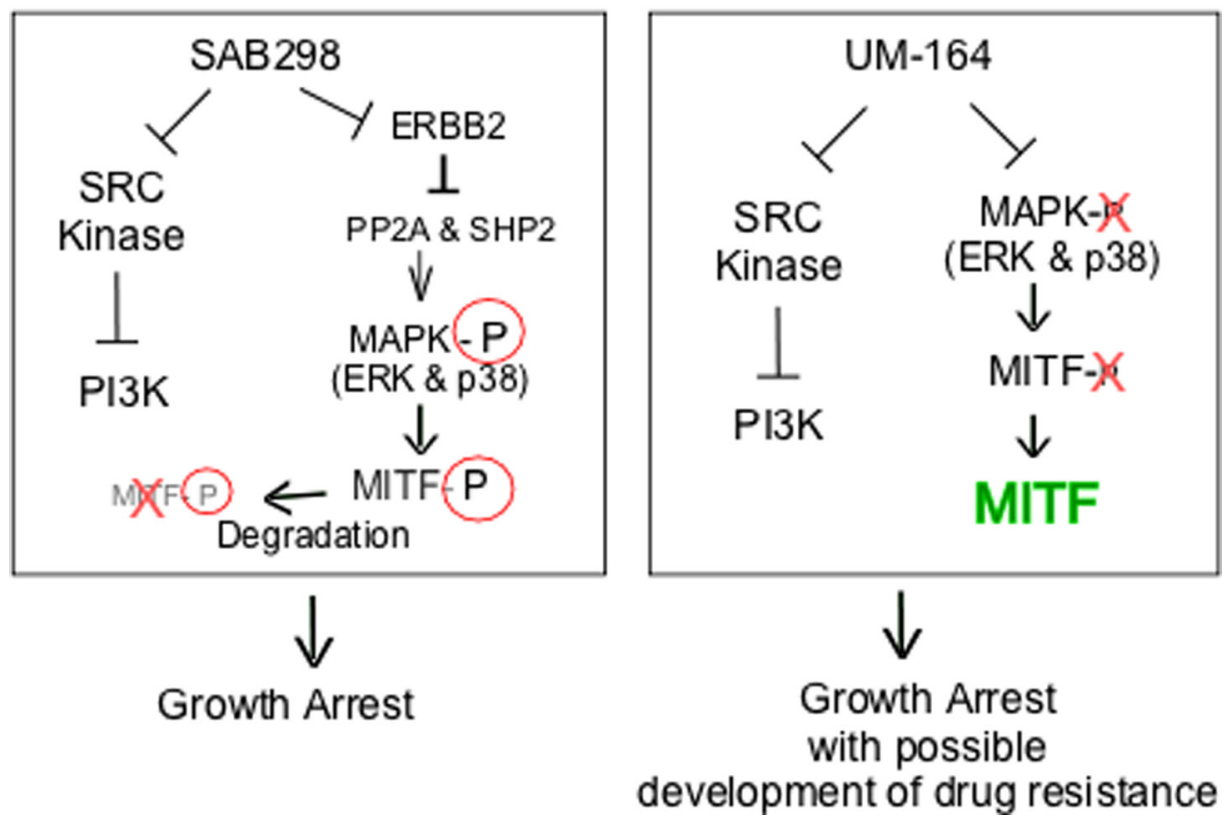

Figure 10: Schematic representation of intracellular signaling induced by SAB298 and UM-164. The figure shows SAB298 and UM-164 common inhibition of SFK and PI3K activities $(\perp)$ that lead to growth arrest but opposite effects on MITF (down- versus upregulation) that may contribute to long term response to the drug, such as development of resistance in the presence of high levels of MITF. 
Tyr204 (\#9101), ERK1/2 (\#9107), phospho-p38 kinase T180/Y182 (\#9216), p38 kinase (\#9212), PP2A (\#2259), pSHP2 Y542 (\#3751), SHP2 (D50F2, \#3397), ERBB2 (D8F12 XP(R), \#4290), phospho-ERBB2 Y1196 (D66B7 \#6942), MYC (D84C12, \#5605); GAPDH (14C10, \#2118), all from Cell Signaling Technology, Beverly, MA; phospho-PP2A Y307 (AF3989), and MITF (clone D5, \#AF5769) from R\&D Systems, Inc., Minneapolis, MN; p27KIP1 (\#10241) and YES (\#610375) from BD Biosciences, San Jose, CA; Cyclin D1 (\#04-221) and $\beta$-actin (mouse mAb A5316) from MilliporeSigma, St. Louis, MO; PI3K Antibody (p85 alpha, NSJ R30480) from Bioreagents, 9921 Carmel Mountain Rd \#352, San Diego, CA. All antibodies were used at the concentrations recommended by the manufacturers.

\section{In vivo mouse studies}

All procedures involving animals were approved by the Institutional Animal Care and Use Committee of Yale University. YUSIK melanoma cells were grown to $80 \%$ confluency in $150 \mathrm{~cm}^{2}$ flasks, detached by trypsinization, washed with PBS, and cell pellets were resuspended in 1:1 mixture of PBS and matrigel (BD Bioscience Cat \#354234) to sustain cell viability. The cells $\left(4 \times 10^{6} / 100\right.$ $\mu 1)$ were injected subcutaneously in the back flank of six weeks old female athymic Nude-Foxn1nu (nu/nu) mice (Charles River Laboratories, Wilmington, MA), and tumors were measuring daily with a caliper (length, width, and depth). When tumors reached palpable size (between $25-40 \mathrm{~mm}^{3}$ ), the animals were randomized by tumor size and body weigh into two groups and were daily injected intraperitoneally with SAB298 (batch \#AU058891, Sabila Biosciences LLC, 5 Overlook Road, New City, New York, 10956) or vehicle as controls $(N=6 /$ each $)$. The injections contained SAB298 $(0.5 \% \mathrm{~W} / \mathrm{V})$ in a solution of PBS (30\%), DMSO (5\%), DMA (5\%), PEG400 (20\%), and PG $(40 \%)$ to assure solubility. The vehicle contained the same reagents but without SAB298.

The tumors size and body weight were measured daily and the mice were checked for clinical signs of toxicity, such as lethargy, neurological symptoms, diarrhea, discharges, morbidity, piloerection and weight loss $(>20 \%)$. None of them or any other abnormal indication were observed.

\section{Abbreviations}

SFK: SRC family kinases; bFGF: basic fibroblast Growth factor; IBMX: isobutyl methyl xanthine; dbcAMP: dibutyryl cyclic AMP; DMSO: dimethyl sulfoxide; DMA: dimethyl acetamide; PG: propylene glycol.

\section{Author contributions}

R.H. supervised the study, performed some of the experiments and wrote the manuscript. A.B. and R.S. performed the experiments. J.C. performed the in vivo studies, contributed to the design of the experiments and the writing of the manuscript. M.S and D.N provided the tissues used to establish melanoma cells lines. A.A. and M.K. performed the statistical analyses. T.S.M. provided SAB298, contributed to the design of the experiments and the writing of the manuscript.

\section{ACKNOWLEDGMENTS}

SAB298 was provided by Sabila Biosciences LLC. We thank the NCI DTP program for testing SAB298 in the NCI 60 panel, and the Functional Genomics Shared Resource Core of the Yale Cancer Center, David A Calderwood and Ben E. Turk, directors, for providing the short hairpin RNA Lentiviral vectors.

\section{CONFLICTS OF INTEREST}

Tarek S. Mansour is the CEO of Sabila Biosciences LLC, NY. None of the other authors have any competing interests.

\section{FUNDING}

Ruth Halaban is supported by the NCI/NIH funded Yale SPORE in Skin Cancer (P50 CA121974), the Milstein-Meyer Award and the Sokoloff family-MRA Team Award; Jian Cao is supported by the Sokoloff family-MRA Team Award. Michael Krauthammer was supported by the NCI/NIH funded Yale SPORE in Skin Cancer (P50 CA121974).

\section{REFERENCES}

1. Bollag G, Hirth P, Tsai J, Zhang J, Ibrahim PN, Cho H, Spevak W, Zhang C, Zhang Y, Habets G, Burton EA, Wong $\mathrm{B}$, Tsang $\mathrm{G}$, et al. Clinical efficacy of a RAF inhibitor needs broad target blockade in BRAF-mutant melanoma. Nature. 2010; 467:596-99. https://doi.org/10.1038/nature09454. [PubMed]

2. Rheault TR, Stellwagen JC, Adjabeng GM, Hornberger KR, Petrov KG, Waterson AG, Dickerson SH, Mook RA Jr, Laquerre SG, King AJ, Rossanese OW, Arnone MR, Smitheman KN, et al. Discovery of Dabrafenib: A Selective Inhibitor of Raf Kinases with Antitumor Activity against B-Raf-Driven Tumors. ACS Med Chem Lett. 2013; 4:35862. https://doi.org/10.1021/ml4000063. [PubMed]

3. Simeone E, Grimaldi AM, Festino L, Vanella V, Palla M, Ascierto PA. Combination Treatment of Patients with BRAF-Mutant Melanoma: A New Standard of Care. 
BioDrugs. 2017; 31:51-61. https://doi.org/10.1007/s40259016-0208-Z. [PubMed]

4. Larkin J, Ascierto PA, Dréno B, Atkinson V, Liszkay G, Maio M, Mandalà M, Demidov L, Stroyakovskiy D, Thomas L, de la Cruz-Merino L, Dutriaux C, Garbe C, et al. Combined vemurafenib and cobimetinib in BRAF-mutated melanoma. N Engl J Med. 2014; 371:1867-76. https://doi. org/10.1056/NEJMoa1408868. [PubMed]

5. Wongchenko MJ, McArthur GA, Dréno B, Larkin J, Ascierto PA, Sosman J, Andries L, Kockx M, Hurst SD, Caro I, Rooney I, Hegde PS, Molinero L, et al. Gene Expression Profiling in BRAF-Mutated Melanoma Reveals Patient Subgroups with Poor Outcomes to Vemurafenib That May Be Overcome by Cobimetinib Plus Vemurafenib. Clin Cancer Res. 2017; 23:5238-45. https://doi. org/10.1158/1078-0432.CCR-17-0172. [PubMed]

6. Gilani RA, Phadke S, Bao LW, Lachacz EJ, Dziubinski ML, Brandvold KR, Steffey ME, Kwarcinski FE, Graveel CR, Kidwell KM, Merajver SD, Soellner MB. UM-164: A Potent c-Src/p38 Kinase Inhibitor with In Vivo Activity against Triple-Negative Breast Cancer. Clin Cancer Res. 2016; 22:5087-96. https://doi.org/10.1158/1078-0432.CCR15-2158. [PubMed]

7. Krauthammer M, Kong $\mathrm{Y}$, Bacchiocchi A, Evans $\mathrm{P}$, Pornputtapong N, Wu C, McCusker JP, Ma S, Cheng E, Straub R, Serin M, Bosenberg M, Ariyan S, et al. Exome sequencing identifies recurrent mutations in NF1 and RASopathy genes in sun-exposed melanomas. Nat Genet. 2015; 47:996-1002. https://doi.org/10.1038/ng.3361. [PubMed]

8. Chou TC, Talalay P. Quantitative analysis of dose-effect relationships: the combined effects of multiple drugs or enzyme inhibitors. Adv Enzyme Regul. 1984; 22:27-55. https://doi.org/10.1016/0065-2571(84)90007-4. [PubMed]

9. Chou TC. Theoretical basis, experimental design, and computerized simulation of synergism and antagonism in drug combination studies. Pharmacol Rev. 2006; 58:62181. https://doi.org/10.1124/pr.58.3.10. [PubMed]

10. Wang Y, Ma H. Protein kinase profiling assays: a technology review. Drug Discov Today Technol. 2015; 18:1-8. https:// doi.org/10.1016/j.ddtec.2015.10.007. [PubMed]

11. Liu W, Kovacevic Z, Peng Z, Jin R, Wang P, Yue F, Zheng M, Huang ML, Jansson PJ, Richardson V, Kalinowski DS, Lane DJ, Merlot AM, et al. The molecular effect of metastasis suppressors on Src signaling and tumorigenesis: new therapeutic targets. Oncotarget. 2015; 6:35522-41. https://doi.org/10.18632/oncotarget.5849. [PubMed]

12. Shaul YD, Seger R. The MEK/ERK cascade: from signaling specificity to diverse functions. Biochim Biophys Acta. 2007; 1773:1213-26. https://doi.org/10.1016/j. bbamcr.2006.10.005. [PubMed]

13. Mkaddem SB, Murua A, Flament H, Titeca-Beauport D, Bounaix C, Danelli L, Launay P, Benhamou M, Blank U, Daugas E, Charles N, Monteiro RC. Lyn and Fyn function as molecular switches that control immunoreceptors to direct homeostasis or inflammation. Nat Commun. 2017; 8:246. https://doi.org/10.1038/s41467-017-00294-0. [PubMed]

14. Zhang S, Fan G, Hao Y, Hammell M, Wilkinson JE, Tonks NK. Suppression of protein tyrosine phosphatase N23 predisposes to breast tumorigenesis via activation of FYN kinase. Genes Dev. 2017; 31:1939-57. https://doi. org/10.1101/gad.304261.117. [PubMed]

15. Perrotti D, Neviani P. Protein phosphatase 2A: a target for anticancer therapy. Lancet Oncol. 2013; 14:e229-38. https://doi.org/10.1016/S1470-2045(12)70558-2. [PubMed]

16. Mohi MG, Neel BG. The role of Shp2 (PTPN11) in cancer. Curr Opin Genet Dev. 2007; 17:23-30. https://doi. org/10.1016/j.gde.2006.12.011. [PubMed]

17. Fisher DE. Microphthalmia: a signal responsive transcriptional regulator in development. Pigment Cell Res. 2000; 13:145-49. https://doi.org/10.1034/j.1600-0749.13. s8.26.x. [PubMed]

18. Wu M, Hemesath TJ, Takemoto CM, Horstmann MA, Wells AG, Price ER, Fisher DZ, Fisher DE. c-Kit triggers dual phosphorylations, which couple activation and degradation of the essential melanocyte factor Mi. Genes Dev. 2000; 14:301-12. [PubMed]

19. Phung B, Kazi JU, Lundby A, Bergsteinsdottir K, Sun J, Goding CR, Jönsson G, Olsen JV, Steingrímsson E, Rönnstrand L. KITD816V Induces SRC-Mediated Tyrosine Phosphorylation of MITF and Altered Transcription Program in Melanoma. Mol Cancer Res. 2017; 15:126574. https://doi.org/10.1158/1541-7786.MCR-17-0149. [PubMed]

20. Homsi J, Cubitt CL, Zhang S, Munster PN, Yu H, Sullivan DM, Jove R, Messina JL, Daud AI. Src activation in melanoma and Src inhibitors as therapeutic agents in melanoma. Melanoma Res. 2009; 19:167-75. https://doi. org/10.1097/CMR.0b013e328304974c. [PubMed]

21. Buettner R, Mesa T, Vultur A, Lee F, Jove R. Inhibition of Src family kinases with dasatinib blocks migration and invasion of human melanoma cells. Mol Cancer Res. 2008; 6:1766-74. https://doi.org/10.1158/1541-7786.MCR-080169. [PubMed]

22. Girotti MR, Lopes F, Preece N, Niculescu-Duvaz D, Zambon A, Davies L, Whittaker S, Saturno G, Viros A, Pedersen M, Suijkerbuijk BM, Menard D, McLeary R, et al. Paradox-Breaking RAF Inhibitors that Also Target SRC Are Effective in Drug-Resistant BRAF Mutant Melanoma. Cancer Cell. 2017; 31:466. https://doi.org/10.1016/j. ccell.2017.02.007. [PubMed]

23. Kluger HM, Dudek AZ, McCann C, Ritacco J, Southard N, Jilaveanu LB, Molinaro A, Sznol M. A phase 2 trial of dasatinib in advanced melanoma. Cancer. 2011; 117:220208. https://doi.org/10.1002/cncr.25766. [PubMed]

24. Kalinsky K, Lee S, Rubin KM, Lawrence DP, Iafrarte AJ, Borger DR, Margolin KA, Leitao MM Jr, Tarhini AA, Koon HB, Pecora AL, Jaslowski AJ, Cohen GI, et al. A phase 2 
trial of dasatinib in patients with locally advanced or stage IV mucosal, acral, or vulvovaginal melanoma: A trial of the ECOG-ACRIN Cancer Research Group (E2607). Cancer. 2017; 123:2688-97. https://doi.org/10.1002/cncr.30663. [PubMed]

25. Lindauer M, Hochhaus A. Dasatinib. Recent Results Cancer Res. 2018; 212:29-68. https://doi.org/10.1007/978-3-31991439-8_2. [PubMed]

26. Anastassiadis T, Deacon SW, Devarajan K, Ma H, Peterson JR. Comprehensive assay of kinase catalytic activity reveals features of kinase inhibitor selectivity. Nat Biotechnol. 2011; 29:1039-45. https://doi.org/10.1038/nbt.2017. [PubMed]

27. Tsao H, Chin L, Garraway LA, Fisher DE. Melanoma: from mutations to medicine. Genes Dev. 2012; 26:1131-55. https://doi.org/10.1101/gad.191999.112. [ubMed]

28. Smith MP, Rana S, Ferguson J, Rowling EJ, Flaherty KT, Wargo JA, Marais R, Wellbrock C. A PAX3/BRN2 rheostat controls the dynamics of BRAF mediated MITF regulation in MITFhigh /AXLlow melanoma. Pigment Cell Melanoma Res. 2019; 32:280-91. https://doi.org/10.1111/pcmr.12741. [PubMed]

29. Johannessen CM, Johnson LA, Piccioni F, Townes A, Frederick DT, Donahue MK, Narayan R, Flaherty KT, Wargo JA, Root DE, Garraway LA. A melanocyte lineage program confers resistance to MAP kinase pathway inhibition. Nature. 2013; 504:138-42. https://doi. org/10.1038/nature12688. [PubMed]

30. Smith MP, Brunton H, Rowling EJ, Ferguson J, Arozarena I, Miskolczi Z, Lee JL, Girotti MR, Marais R, Levesque
MP, Dummer R, Frederick DT, Flaherty KT, et al. Inhibiting Drivers of Non-mutational Drug Tolerance Is a Salvage Strategy for Targeted Melanoma Therapy. Cancer Cell. 2016; 29:270-84. https://doi.org/10.1016/j. ccell.2016.02.003. [PubMed]

31. Aida S, Sonobe Y, Tanimura H, Oikawa N, Yuhki M, Sakamoto H, Mizuno T. MITF suppression improves the sensitivity of melanoma cells to a BRAF inhibitor. Cancer Lett. 2017; 409:116-24. https://doi.org/10.1016/i. canlet.2017.09.008. [PubMed]

32. Halaban R, Zhang W, Bacchiocchi A, Cheng E, Parisi F, Ariyan S, Krauthammer M, McCusker JP, Kluger Y, Sznol M. PLX4032, a selective BRAF(V600E) kinase inhibitor, activates the ERK pathway and enhances cell migration and proliferation of BRAF melanoma cells. Pigment Cell Melanoma Res. 2010; 23:190-200. https://doi.org/10.1111/ j.1755-148X.2010.00685.x. [PubMed]

33. Krauthammer M, Kong Y, Ha BH, Evans P, Bacchiocchi A, McCusker JP, Cheng E, Davis MJ, Goh G, Choi M, Ariyan $\mathrm{S}$, Narayan D, Dutton-Regester K, et al. Exome sequencing identifies recurrent somatic RAC1 mutations in melanoma. Nat Genet. 2012; 44:1006-14. https://doi.org/10.1038/ ng.2359. [PubMed]

34. Patricelli MP, Nomanbhoy TK, Wu J, Brown H, Zhou D, Zhang J, Jagannathan S, Aban A, Okerberg E, Herring C, Nordin B, Weissig H, Yang Q, et al. In situ kinase profiling reveals functionally relevant properties of native kinases. Chem Biol. 2011; 18:699-710. https://doi.org/10.1016/j. chembiol.2011.04.011. [PubMed] 